DOI 10.18551/rjoas.2020-05.05

\title{
FACTORS AFFECTING THE PURCHASE OF LOCAL AGRICULTURAL COMMODITIES
}

\author{
Prayana I Made Dwi*, Yuliarmi Ni Nyoman \\ Faculty of Economics and Business, University of Udayana, Bali, Indonesia \\ ${ }^{*}$ E-mail: made.dwipa@gmail.com
}

\begin{abstract}
The government is trying to encourage more local agricultural commodities to be absorbed by the market. One of them is by encouraging consumers to buy more locally- produced food. This is expected to provide economic, environmental, and social benefits for local people, leading to more sustainable consumption. This study looks at the factors that influence the purchase of local agricultural commodities. By reviewing the literature on similar studies conducted, this study found the Theory of Planned Behavior is often used to test the purchasing behavior of local agricultural products. Several factors were found to influence the intention to buy local products including those related to perceptions of intrinsic factors such as quality, health, and food safety, and extrinsic factors such as consumer ethnocentrism, concern for the local economy, and environmental impact.
\end{abstract}

\section{KEY WORDS}

Local agricultural products, theory of planned behavior, consumer behavior.

One of the effects of globalization is increasing competition between local and foreign companies in the market. In America, the consumption of local agricultural products has doubled compared to 2008 (USDA, 2015). While in Europe the trend of short-distance food supply also shows an increase (Kneafsey et al., 2013). In Indonesia, the government continues to strive to absorb more local agricultural products in the market. One of them is by issuing the Presidential Regulation of the Republic of Indonesia Number 22 Year 2009 concerning the Policy for the Acceleration of Diversification of Local Resource-Based Food Consumption. At the regional level, the Provincial Government of Bali is also intensively conducting a campaign to consume local products. One of them is by issuing policies in the form of Bali Governor Regulation No. 99 of 2018 concerning Marketing and Utilization of Bali's Agriculture, Fisheries and Local Industry Products. Consumption of local products is considered good for the local economy. Purchasing local products keeps money circulating in the local community. Consumption of local products also makes the local economy more resilient to the threat of recession.

Another positive side of the consumption of local products is their impact on the environment. Consumption of local products is part of sustainable consumption which is one of the United Nations' sustainable development agendas (UN, 2019). In Bali, for example, there is a Subak local wisdom that is threatened by the increasingly massive conversion of agricultural land functions (Wiraraja et al., 2016). Agriculture in a broad sense continues to contribute considerably to the Gross Regional Domestic Product (GRDP) of the Province of Bali. Some of the leading local agricultural commodities owned by the province of Bali are coffee, chocolate, cashew, and organic rice. Some of these superior agricultural commodities have even been successfully exported, such as mangosteen fruit, salak fruit, neem leaves, reeds, orchids, swallow's nests, silk cocoons, chicks, and snake skins. The results of the research of Rai et al. (2016) each district in Bali has superior fruit commodities. However, based on BPS data (2019), the contribution of agriculture, forestry, and fisheries to the GRDP of the Province of Bali has decreased from 17.71 percent in 2010 to 13.67 in the third quarter of 2019. While the role of the agricultural sector on the Bali economy has decreased from 15, 22 in 2013 to 13.81 in 2018. This condition needs to get the attention of the government so that the agricultural sector can be more desirable.

Therefore there are several important reasons for knowing the factors that influence the purchase of local agricultural commodities. First, knowing the motivation of consumers can 
increase the absorption of local agricultural commodities whose impact provides welfare to local farmers scattered in rural areas. With the increasing welfare of local farmers, development equality can be created which also prevents population migration to urban areas. Besides that, a prosperous farmer will not pawn his agricultural land, so that it will suppress the land-use change. Second, increasing the uptake of local agricultural commodities is beneficial to the environment and supports sustainable production and consumption. By absorbing local agricultural commodities, carbon emissions resulting from transportation can be reduced. Also, with the preservation of agricultural land, the negative effects of industrial-based development such as pollution and reduced water catchment areas can be suppressed. And the most important thing is to maintain the consumption of local agriculture to maintain biodiversity due to the absorption of local agricultural commodities that do not exist in other areas and to maintain local culture-based agricultural wisdom. By reviewing the literature, this paper examines what factors in previous studies were considered to influence consumer motivation in purchasing local agricultural commodities.

\section{RESULTS AND DISCUSSION}

Definition of Local Agricultural Products. Research shows adaptive consumers in their interpretations of what local meanings are based on where they live and the types of agricultural products available to them (Roper et al., 2015). Consumers in America generally define local agricultural products as agricultural products grown in a neighboring area or district, or the state (Harris et al., 2000; Wilkins et al., 2002). According to Printezis et al. (2019), discussions about the definition of local products occur around the location of the planting (city, province, or region), logo/brand/label, or distance from the point of sale. While Zepeda and Leviten-Reid (2004) found consumers who considered the product to be called local based on the time taken from where it was produced to where it was sold/consumed. James et al. (2009) say the product is called local if it is produced within 100 miles of the point of sale or regional boundary. These definitions indicate that local agricultural products do not have to be labeled by the state but can also be specific cities, provinces, or regions and even local products can be defined based on distances not related to political boundaries.

Arsil et al., (2014) found that most Indonesian consumers interpreted local agricultural products as agricultural products produced by local villages, the second-largest interpreted local products as city/district products and the third was local agricultural products as provincial products. Very few interpret local as a state product. In Bali, Bali Governor Regulation No. 99 of 2018 defines Local Agricultural Products as agricultural products derived from aquaculture in the Bali region. Bali mentioned in this regulation refers to the province of Bali. So local products in Bali use the provincial political boundaries and not based on distance. According to Waltz (2011), local agricultural products are not only a matter of distance from the place of consumption but also a matter of social structure and distribution channels that are different from modern supermarket systems. Based on the location of consumers, certain fruits or vegetables may not be planted in their state or region so consumers are willing to expand their "local" definition to cover the closest area available for them to buy products (Roper et al., 2015). This is according to Trivette (2015) because local concepts can be defined through two things, namely physical location, and personal connections. In terms of physical proximity, the product is called local based on how many miles the product will travel from the producer to the consumer. Meanwhile, in terms of personal connections, the product is called local because there is a component of cultural relations and personal relationships in it. According to the Governor of Bali Regulation No. 99 of 2018, which includes local agricultural products include food crops, horticulture, plantations, and livestock. As for Food Crops, Horticulture and Plantations that are utilized and marketed are produced from farms carried out in Bali; produced from gardens, land or business units that have been registered by the Office; and have quality assurance and food safety in the form of certificates; register; or Certificate. Whereas Bali Local Animal Products 
that are utilized and marketed must be produced from animal husbandry businesses carried out in Bali; have food quality and safety guarantees in the form of veterinary control number certificate; or other certificate.

Consumer Choice. Many factors influence consumer purchases. According to Gabriel and Lang (2003), there are five main approaches to consumer behavior. The first is consumerism as a moral doctrine. In this approach, consumerism is seen as the core of a better life and a vehicle for freedom, strength, and happiness. Second, consumerism as a conspicuous ideology of consumption. Consumption is seen as a determinant and enhancer of social status. Third, consumerism as an economic ideology. Consumption is seen as a source of economic life, so maintaining consumption needs is the key to economic development. Fourth, consumerism as a political ideology which means the politicization of consumption both in terms of the state guarantees the rights of consumers and the state as the main provider of goods, services, and quality standards. Fifth, consumerism as a social movement. This means that consumption as consumer advocacy, not only in the form of quality-related concerns but also in the form of criticism of excessive consumption and the world with limited resources.

Strengths and Weaknesses of Local Agricultural Products. Defra (2005) believes that food, including agricultural products, consumed closer to the point of production has the potential to provide economic, environmental, and social benefits concerning sustainable consumption at the local level. Consumer perceptions of the advantages of local agricultural products generally come from things such as health, organic, and sensory characteristics (taste, aroma, color, texture), as well as a small portion related to social and environmental benefits (Nistor, 2016). In a survey of 200 respondents in the US in 2012, individuals who were concerned about food safety and health were more likely to buy local agricultural products (Maples et al., 2013). The study conducted by Loke et al. (2015) estimates that milk prices in Hawaii, US will increase by 17 percent if the product is produced locally, and by 25 percent if it is local and organic. This will certainly affect the welfare of local dairy producers. Although on the other hand, a more expensive price can be a barrier for local consumers. For consumers, factors such as higher prices, unattractive packaging, and availability problems become a lack of local agricultural products (Nistor, 2016). Empirical studies show consumers tend to value alternative food products such as local, traditional and organic products more expensive than conventional products (Barnett et al., 2005; Adams and Adams, 2011; Johnston et al., 2011). Buying food grown locally is also proven to have obstacles and limitations for consumers. These barriers include location, number of trips needed, price, and comfort (Roper et al., 2015).

Factors That Influence Local Product Purchases. The demand for local agricultural products is influenced by many things. To find out consumer behavior towards the purchase of local agricultural products, some researchers use the Theory of Planned Behavior (Vermeir \& Verbeke, 2006; Rainbolt et al., 2012; Bianchi \& Mortimer, 2015; Raygor, 2016; Shin et al., 2016; Giampietri, 2017; Holt et al., 2018; Kumar \& Smith, 2017). This theory was developed by Fishbein and Ajzen (1975) and perfected by Ajzen (2015). According to the Theory of Planned Behavior, a person's behavior is preceded by their intention to perform the behavior. Intentions, in turn, are related to a set of variables including Attitudes, Subjective Norms, and Behavioral Control. Attitude refers to a person's positive or negative beliefs about certain behaviors. Subjective Norms are social perceptions that one feels about a behavior. Behavioral Control is the ability of one's perception to perform a behavior. According to Ajzen (1991), if Attitudes, Subjective Norms, and Behavioral Control are strong, the intention will be strong, which will lead someone to carry out the behavior given. In Planned Behavior Theory, Attitude is seen as an important determinant of intentions and subsequent behavior. The Planned Behavior Theory has been successfully applied to study intentions and behavior in various domains, including food consumption (Fishbein \& Ajzen, 2010). Many studies of food consumption stop at predictive intentions, but others also collect behavioral data. The results of a sample study of Planned Behavior Theory of food consumption indicate that the Planned Behavior Theory provides good predictions about 
various intentions related to food, including the intention to consume local agricultural products.

In most cases, one's attitude or preference is the strongest predictor of intention (Conner et al., 2002; Bianchi \& Mortimer, 2015; Shin, 2016; Giampietri, 2017; Kumar \& Smith, 2017). The exception is the consumption of healthy foods (Conner et al., 2002). In the case of a healthy diet that refers to products low in fat, high in fiber, and fruits and vegetables. Regression coefficient inspection shows that behavioral control is the strongest predictor of consuming healthy food. This shows that anticipating difficulties in maintaining a healthy diet reduces people's intention to engage in this behavior. Holt (2018) found that selfidentity or moral obligation was a significant predictor of consumers' intention to buy locally grown blueberries. The results show consumers are compelled to buy local agricultural products if they are by their identity and moral obligations. By modeling structural equations, Giampietri et al. (2017) confirm the role of Trust as a direct antecedent of consumer intention to buy food in short chains where attitude factors are the most influential compared to Subjective Norms and Behavioral Control in the standard Planned Behavior Theory model. The investigation found that rural consumer dwellings and fair trade purchase habits, in addition to behavioral intentions and controls, influence behavior.

Kumar and Smith (2017) found that health awareness, concern for the environment, and concern for the local economy are significant predictors of attitudes towards local agricultural products which, in turn, were found to have a significant influence on intentions to buy local agricultural products. With the Theory of Planned Behavior, Bianchi and Mortimer (2015) find that the strongest driver of consumption of local agricultural products is the attitude towards local agricultural products. Shin (2016) found subjective norms did not affect, but attitudes and behavioral control could predict local product purchases with planned behavior theory. Behavior and behavioral control are important antecedents of the intentions and / or behavior of actual purchase of local agricultural products, which are consistent with planned behavior theory and previous findings in the context of food (Sparks \& Shepherd, 1992; Robinson \& Smith, 2002; Arvola et al., 2008; Vermeir \& Verbeke, 2008). Suitability affects attitudes, subjective norms, and control of behavior directly. This relationship is consistent with previous research (Tajfel, 1982; Shaw \& Shiu, 2002; Hagger et al., 2007; Arvola et al., 2008; Kang et al., 2012). Thus, individuals who think of their selfimage in line with the consumption of local agricultural products will also have a more positive attitude, feel more social pressure, and feel more control over purchasing local agricultural products. Research Rainbolt et al. (2012) show that the full model of the Planned Behavior Theory is not significant for locally grown tomatoes and does not help explain variations in willingness to pay. On the other hand, the full model of the Planned Behavior Theory successfully explained the behavioral intentions of locally grown apples. One significant predictor is the social norm and the perception of consumer effectiveness (PCE). It is important to note that PCE remains a significant predictor of willingness to pay (WTP) and that incorporating social norms into the model further enhances the explanatory power of the model. The stepwise multiple regression model shows that 50 percent of the variance in the intention to consume sustainable milk is explained by a combination of personal attitudes, perceived social influence, effective consumer perceptions, and perceived availability (Vermeir \& Verbeke, 2008).

Goodwin (2013) found Florida consumers to have a good attitude towards purchasing local agricultural products, supporting the local economy through buying local agricultural products, engaging with where their food was grown, and knowing how their food was grown. Key attributes that influence consumers 'intention to buy local agricultural products, including product availability, price, convenience, farmers' trust, and awareness. Aprile et al. (2015) show that the tendency to choose local agricultural products depends on factors such as special attention to food quality; ethnocentric behavior, which encourages consumers to prefer domestic products over foreign ones; and preferences expressed by consumers for local products. However, social and cultural motivations related to supporting local farmers as well as environmental problems were also found as significant factors in explaining consumers' positive attitudes towards local food. Factors associated with attention to quality 
certification with special reference to geographical indication labels and Organic Agriculture labels also play an important role in understanding consumer attitudes towards local agricultural products.

Zepeda and Li (2006) found attitudes toward cooking and prices were significantly related to local buying behavior; the pleasure of cooking significantly increases the likelihood of buying local agricultural products, while concerns about the cost of food significantly reduce the likelihood of buying local agricultural products. Buyers of organic agricultural products are consumers who seem to appreciate aspects of food production. Nganje (2011) shows that consumers are willing to pay a premium of $\$ 0.18$ per pound for local spinach that is marked by the Arizona Grown label for local unnamed spinach. This premium is higher than the $\$ 0.10$ premium that will be paid for state-brand carrots. This difference highlights consumers' perceptions about being grown locally as an indicator, or "gesture," of safety in their food supply.

Carpio \& Isengildina-Massa (2009) findings show that South Carolina consumers are willing to pay an average premium of 27 percent for locally grown products and 23 percent for local animal products. Jekanowski (2000) found that household income, perceived quality of Indiana's agricultural products, and the length of time consumers spend in the state are all positively related to the possibility of purchasing agricultural products produced in the state. The level of education has a negative effect. He also found a significant difference between male and female respondents, and women were more likely to buy locally produced agricultural products. Product quality is very important, because the perceived quality is found to have the strongest positive effect on the likelihood of a purchase. Purchasing local agricultural products has macro and micro values. At the macroeconomic level, local agricultural consumption is considered positive for environmental reasons. Because the consumption of local products reduces the quantity of use of renewable energy produced from food transportation. Consumption of local agricultural products is also a political project that aims to build the local economy by giving local communities the right to build their food supply. In addition, the localization of the food supply system creates a direct relationship between producers and consumers. At the micro-level or on the consumer side, local products have many benefits that are usually associated with health issues, trust (because they know the origin of food), freshness, authenticity and the existence of personalized commercial relationships (Nistor, 2016).

Several academic studies have explored consumer perceptions and behavior regarding consumption of local agricultural products (Zepeda \& Leviten-Reid, 2004; Mirosa \& Lawson, 2012; Rainbolt et al., 2012; Arsil et al., 2013; Autio et al., 2013). Apart from increasing the consumption behavior of local agricultural products, research to find out the buying behavior of local agricultural products is still limited (Weatherell et al., 2003). Literature review shows that most previous research focuses on food systems, policies and distribution (Hinrichs, 2000; Duffy et al., 2005; Ilbery et al., 2006; Alonso \& O'Neill, 2010; Coderre et al., 2010; Pearson et al., 2010) al., 2011). Studies that have explored consumer preferences, attitudes and behavioral intentions towards local agricultural products have largely been carried out in developed countries, where sales of local agricultural products are mostly conducted through supermarkets, which have dominated the retail market (Alonso \& O'Neill, 2010 ; Lang et al., 2014).

From some studies, there are two different approaches concerning the issue of local agricultural products between the perspectives of North American consumers (the United States and Canada) and European countries (Goodman, 2003; Holloway et al., 2007; Vecchio, 2010). The North American perspective views local production as an alternative agricultural system based on the principles of social justice and environmental sustainability, which aims to rebuild relations between producers and consumers (Fonte, 2008). About the principle of social justice, the local agricultural system is seen as one in which economic power, material resources, and profits are shared equitably among people in a particular community (Allen, 2010). As for the preservation of the environment, by reducing the physical distance between producers and consumers, the local agricultural system is seen to be able to reduce the environmental impacts associated with food transportation around the 
world (Seyfang, 2006). Finally, local agricultural production requires short supply chains, thus making consumer and producer relations closer (Hinrichs, 2000; Morgan et al., 2006).

In developing countries, studies on the behavior of consumption of local agricultural products are still minimal. Even so the results of research that have been done in developing countries related to factors that influence the purchase of local products are in line with what is found in developed countries (Arsil et al., 2014, 2016). Research in Indonesia conducted by Arsil et al. (2016) on some positive attributes of local agricultural products that motivate consumers to put health attributes as the most influential. Health and environmental care attributes are increasingly influential if the product is organic (Khorniawati, 2014; Ratnawati \& Mansoni, 2018). Another positive attribute is a sense of achievement that can be linked to ethnocentrism, family / regional / state welfare and lower prices. The influence of ethnocentrism on the purchase of local agricultural products in Indonesia was also found in the research of Anggasari, et al (2013) and Monalisa (2015). Consumers in Indonesia, including in Bali, generally prefer local products to imported products (Monalisa, 2015; Sumarwan \& Palupi, 2017; Dwiastari et al., 2019). The price attribute becomes important for Indonesian consumers because the price of local agricultural products is believed to be lower than imported products (Arsil et al., 2014; Dwiastari et al., 2019, Wahyudi et al., 2019). Other influential factors are taste, color, size, taste, level of income and continuity of availability (Dwiastari et al., 2019). As a tourism area, the demand for local agricultural products in Bali does not only come from markets and supermarkets. Consumers of local agricultural products also come from the tourism accommodation industry such as hotels and restaurants. Some factors that affect the demand for local fruit in starred hotels include quality, price, hotel policy, continuity and government policies where the most dominant factor is quality (Sumawidari et al., 2013). According to Wirawan et al. (2014) the competitiveness of local fruits is influenced by several factors such as (1) planting conditions, (2) how to harvest (sorting, packaging, transportation, incentives for farmers), (3) quality (appearance, durability, nutrient content and taste), (4) marketing channels and (5) regulations (Regional Regulations, Awig-Awig and Perarem). Hotels generally use local fruit because local fruit is fresher than imported fruit, local fruit does not travel too long and local fruit is picked from the garden in a relatively mature and directly marketed condition that is different from imported fruit through a long shipping process and packaging. use preservatives to make vitamins and nutrients contained reduced. The existence of a long distribution channel also has an impact on the price of imported fruit more expensive compared to local fruit, because the hotel serves fruit every day will have an impact on hotel spending. Presentation of daily fruit can also introduce the uniqueness of Indonesia's local fruit to tourists and foster a sense of love for local products. (Adeliani, 2015)

\section{CONCLUSION AND SUGGESTIONS}

Awareness of buying local agricultural products in developed countries has occurred for a long time. Generally this is caused by concern for the welfare of local farmers impacting the environment. Therefore, in developed countries like the United States and the United Kingdom, research on consumer preferences for local agricultural commodities has been done quite a lot.

In developing countries such as Indonesia, research on consumer preferences for local agricultural commodities is still minimal. However, some researchers have tried to examine the factors that influence the purchase of local agricultural products, including in Bali Province.

Many researchers use the Theory of Planned Behavior (TPB) to predict the intention of consumers to purchase local agricultural products. This psychological theory is widely used to determine consumption behavior related to attitudes, social norms and behavior control. Attitude is the most common indicator found to influence consumer intention to buy local agricultural products. Some researchers use TPB to confirm extrinsic factors that influence consumer attitudes such as ethnocentrism, environmental concern and concern for the local 
economy. Researchers in Indonesia generally use a multi-attribute Fishbein analysis that more measures intrinsic factors such as price and product quality.

Extrinsic matters that affect consumer interest in local agricultural products include health and food safety considerations, consumer ethnocentrism, environmental stewardship, concern for the local economy, income levels and continuity of availability. While the intrinsic factors inherent in the product and affect consumers include price, quality, taste, appearance, size and taste. In several studies, it turns out that gender variables also affect the consumption of local products.

In contrast to developed countries, the consumption of local products in developing countries such as Indonesia is generally influenced by lower prices and tastes that suit your taste. Consumer ethnocentrism was also found to influence the consumption of local agricultural products in Indonesia. In terms of tourism consumption such as in Bali, quality is the most influential factor in the availability of accommodation businesses to buy local agricultural products. Other influential factors are continuity of availability, price and government policy or hotel policy itself.

Research on factors that influence consumers' intention to buy local agricultural products in developing countries such as Indonesia is still minimal, especially those related to extrinsic factors such as concern for the local economy, culture and the environment. Though awareness of this has begun to emerge even though it is not like European countries and America where consumers who have environmental awareness are willing to pay more for local agricultural products.

Based on the challenges and challenges that exist in the development of communitybased tourism villages, the following can be agreed upon:

1. Barriers to the consumption of local agricultural products including location, distance, price, and convenience. Therefore the government should consider facilitating local agricultural products to get a good selling place, for example in markets, supermarkets or tourism accommodation. The government can also hold festivals or farm markets at certain times to bring consumers closer to local agricultural producers;

2. Quality is still the concern of consumers in comparing local agricultural products with imported products. For that the government needs to pay attention to the flow of production and distribution of agricultural products. The government together with academics and the private sector need to work together to develop systems and technologies that guarantee the quality of local agricultural products that are competitive with imported products.

\section{REFERENCES}

1. Adams, D. C., \& Adams, A. E. (2011). De-placing local at the farmers' market: Consumer conceptions of local foods. Journal of Rural Social Sciences, 26 (2), 74-100.

2. Adeliani, I G. A. D. (2015). Alasan dan Hambatan Penyajian Buah Lokal dalam Operasional Hotel Berbintang di Sanur. JUMPA, 2(1), 150-164.

3. Ajzen, I. (1991). The theory of planned behavior. Organizational Behavior and Human Decision Processes, 50(2), 179-211.

4. Ajzen, I. (2015). Consumer attitudes and behavior: The theory of planned behavior applied to food consumption decisions. Rivista di Economia Agraria. 70. 121-138.

5. Ajzen, Icek, and Martin Fishbein (2010), Predicting and Changing Behavior: The Reasoned Action Approach. New York: Psychology Press.

6. Allen, P. (2010). Realizing justice in local food systems. Cambridge Journal of Regions, Economy, and Society, 3, 295-308.

7. Alonso, A.D., \& O'Neill, M. (2010), Small hospitality enterprises and local produce: a case study, British Food Journal, 112(11), 1175-1189.

8. Aprile, M. C., Caputo, V., \& Nayga, R. M. (2015). Consumers' Preferences and Attitudes toward Local Food Products. Journal of Food Products Marketing, 22(1), 19-42. 
9. Arsil, P., Li, E., \& Bruwer, J. (2014), Perspectives on consumer perceptions of local foods: a view from Indonesia, Journal of International Food \& Agribusiness Marketing, 26(2), 107-124.

10. Arsil, P., Li, E., \& Bruwer, J. (2016). Using Means-end Chain Analysis to Reveal Consumers' Motivation for Buying Local Foods: An Exploratory Study. Gadjah Mada International Journal of Business, 18(3), 285.

11. Autio, M., Collins, R., Wahlen, S., \& Anttila, M. (2013), Consuming nostalgia? The appreciation of authenticity in local food production, International Journal of Consumer Studies, 37(5), 564-568.

12. Barnett, C. P., Cloke, N. Clarke, Malpass, A. (2005). Consuming ethics. Articulating the subjects and spaces of ethical consumption. Antipode, 37: 23-45.

13. Blake, M. K., Mellor, J., \& Crane, J. (2010). Buying local food: Shopping practices, place, and consumption networks in defining food as "local". Annals of the Association of American Geographers, 100(2), 409-426.

14. Bruhn, C. M., Vossen, P. M., Chapman, E. \& Vaupel, S. (1992). Consumer attitudes toward locally grown produce. California Agriculture. 46(4):13-16.

15. Badan Pusat Statistik Provinsi Bali. (2018, February 15). Penduduk Provinsi Bali Menurut Agama yang Dianut Hasil Sensus Penduduk 2010. Retrieved January 20, 2020, from https://bali.bps.go.id/statictable/ 2018/02/15/33/penduduk-provinsi-bali-menurut-agamayang-dianut-hasil-sensus-penduduk-2010.html.

16. Carpio, C. E., \& Isengildina-Massa, O. (2009). Consumer willingness to pay for locally grown products: The case of South Carolina. Agribusiness, 25(3), 412-426.

17. Carrus, G., Nenci, A. M., \& Caddeo, P. (2009). The role of ethnic identity and perceived ethnic norms in the purchase of ethnical food products. Appetite, 52(1), 65-71.

18. Cleave, E., Arku, G., Sadler, R., \& Gilliland, J. (2016). The role of place branding in local and regional economic development: bridging the gap between policy and practicality. Regional Studies, Regional Science, 3(1), 207-228.

19. Climate Transparency. (2019, January 15). Indonesia, Country Profile 2018. Retrieved January 20, 2020, from https://www.climate-transparency.org/media/indonesia- countryprofile-2018.

20. Coderre, F., Boivin, C., \& Etaabaa, I. (2010), Measuring retailers' commitment toward regional foods: the CIBLE-chaire bombardier index. British Food Journal, 112(11), 11901204.

21. Conner, D., Colasanti, K., Ross, R. B., \& Smalley, S. B. (2010). Locally Grown Foods and Farmers Markets: Consumer Attitudes and Behaviors. Sustainability, 2(3), 742-756.

22. Conner M., Norman P., \& Bell R. (2002). The theory of planned behavior and healthy eating. Health Psychology, 21(2): 194-201.

23. DEFRA. (2005). The validity of food miles as an indicator of sustainable development. London: Defra.

24. Duffy, R., Fearne, A. and Healing, V. (2005), Reconnection in the UK food chain. Bridging the communication gap between producers and consumers. British Food Journal, 107(1), 17-33.

25. Dwiastari, K. Y., Susrusa, K. B., \& Artini, W. P. (2019). Analisis Preferensi Konsumen terhadap Buah Jeruk Impor dan Buah Jeruk Lokal di Kota Denpasar, Bali. Jurnal Agribisnis dan Agrowisata, 8(3), 391-400.

26. Elliott, G. R., \& Cameron, R. C. (1994). Consumer Perception of Product Quality and the Country-of-Origin Effect. Journal of International Marketing, 2(2), 49-62.

27. Gabriel, Y., \& Lang, T. (2006). The Unmanageable Consumer, second edition. London: Sage.

28. Giampietri, E., Verneau, F., Giudice, T. D., Carfora, V., \& Finco, A. (2018). A Theory of Planned behaviour perspective for investigating the role of trust in consumer purchasing decision related to short food supply chains. Food Quality and Preference, 64, 160-166.

29. Giovannucci, D., Barham, E., \& Pirog, R. (2010). Defining and marketing "local" foods: Geographical indication for US products. The Journal of World Intellectual Property, 13(2), 94-120. 
30. Goodman, D. (2003). The quality "turn" and alternative food practices: Reflections and agenda. Journal of Rural Studies, 19, 1-7.

31. Goodwin, J. N. (2013). Local choice (Research Report). Retrieved from Center for Public Issues Education in Agriculture and Natural Resources Website: http://www.piecenter.com/wp-content/uploads/ 2014/05/FDACS-Local-Choice-ReportFINAL.pdf.

32. Harris, B., Burress, D., Mercer, S., Oslund, P., \& Rose, C. (2000). Kaw Valley Focus Groups on Local and Organic Produce. University of Kansas, IPPBR Report No. 254B.

33. Hinrichs, C. (2000), Embeddedness and local food systems: notes on two types of direct agricultural market. Journal of Rural Studies, 16(3), 295-303.

34. Holloway, L., Kneafsey, M., Venn, L., Cox, R., Dowler, E., \& Tuomainen, H. (2007). Possible food economies: A methodological framework for exploring food productionconsumption relationships. Sociologia Ruralis, 47, 1-15.

35. Ilbery, B., Watts, D., Simpson, S., Gilg, A. \& Little, J. (2006), Mapping local foods: evidence from two English regions. British Food Journal, 108(3), 213-215.

36. James, J. S., Rickard, B. J., \& Rossman, W. J. (2009). Product Differentiation and Market Segmentation in Applesauce: Using a Choice Experiment to Assess the Value of Organic, Local, and Nutrition Attributes. Agricultural and Resource Economics Review, 38(3), 357-370.

37. Jekanowski, M. D., Williams, D. R., \& Schiek, W. A. (2000). Consumers' Willingness to Purchase Locally Produced Agricultural Products: An Analysis of an Indiana Survey. Agricultural and Resource Economics Review, 29(01), 43-53.

38. Johnston, J., Szabo, M., Rodney, A. (2011). Good food, good people. Understanding the cultural repertoire of ethical eating. Journal of Consumer Culture, 11:293-318.

39. Holt, J., Rumble, J. N., Telg, R., \& Lamm, A. (2018). Understanding Consumer Intent to Buy Local Food: Adding Consumer Past Experience and Moral Obligation Toward Buying Local Blueberries in Florida Within the Theory of Planned Behavior. Journal of Applied Communications, 102(2).

40. Khairani, Z., \& Rasyid Abdillah, M. (2018). Sikap Terhadap Kampanye 100\% Cinta Indonesia, Etnosentrisme Konsumen dan Kesediaan Membeli Produk Lokal Indonesia. Jurnal Ilmu Manajemen Daya Saing, 4(3).

41. Khorniawati, M. (2014). Produk Pertanian Organik di Indonesia: Tinjauan Atas Preferensi Konsumen Indonesia Terhadap Produk Pertanian Organik Lokal. Jurnal Studi Manajemen, 8(2), 171-182.

42. Kumar, A., \& Smith, S. (2017). Understanding Local Food Consumers: Theory of Planned Behavior and Segmentation Approach. Journal of Food Products Marketing, 24(2), 196215.

43. Lang, M., Stanton, J., \& Qu, Y. (2014), Consumers' evolving definition and expectations for local food, British Food Journal, Vol. 116 No. 11, pp. 1808-1820.

44. Maples, M., Morgan, M. K., Interis, M. G., \& Harri, A. (2013). Who buys food directly from producers in the Southeastern United States? Journal of Agricultural and Applied Economics, 45(3), 509-518.

45. Mirosa, M., \& Lawson, R. (2012), Revealing the lifestyles of local food consumers. British Food Journal, 114(6), 816-825.

46. Monalisa, T. (2015). Pengaruh Etnosentrisme Konsumen Kota Malang terhadap Niat Beli Buah Lokal. Parsimonial, 2(2), 23-33.

47. Morgan, K., Marsden, T., \& Murdoch, J. (2006). Worlds of food: Place, power, and provenance in the food chain. New York, NY: Oxford University Press.

48. Nganje, W. E., Hughner, R. S., \& Lee, N. E. (2011). State-Branded Programs and Consumer Preference for Locally Grown Produce. Agricultural and Resource Economics Review, 40(01), 20-32.

49. Nistor, L. (2016). The Puzzles of Local Food Consumption: Empirical Insights regarding Profiles, Motivation, and Discourses. Cluj-Napoca: Presa Universitara Clujeana.

50. Onozaka, Y., Nurse, G., \& McFadden, D. T. (2010). "Local Food Consumers: How Motivations and Perceptions Translate to Buying Behavior." Choices, 25(1). 
51. Pearson, D., Henryks, J., Trott, A., Jones, P., Parker, G., Dumaresq, D., \& Dyball, D. (2011), Local food: understanding consumer motivations in innovative retail formats, British Food Journal, 113(7), 886-899.

52. Printezis, I., Grebitus, C., \& Hirsch, S. (2019). The price is right!? A meta-regression analysis on willingness to pay for local food. PloS one, 14(5), [e0215847].

53. Rai, I N., Wijana, G., Sudana I P., Wiraatmaja, I W., Semarajaya, C. G. A., Astiari, N. K. A. (2016). Jurnal Hortikultura Indonesia, 7(1): 31-39.

54. Rainbolt, G.N., Onozaka, Y. and Mcfadden, D.T. (2012), Consumer motivations and buying behavior: the case of the local food system movement. Journal of Food Products Marketing, 18(5), 385-396.

55. Ratnawati, A. \& Mansoni L. (2018). Analisis Faktor-Faktor Green Purchase Intention untuk Meningkatkan Potensi Lokal Usaha Tanaman Organik dan Ketahanan Pangan di Kota Bandung. Jurnal Sekretaris dan Administrasi Bisnis, II(1), 51-67

56. Raygor, A. D. (2016). The Theory of Planned Behavior: Understanding Consumer Intentions to Purchase Local Food in lowa. (2016). Graduate Theses and Dissertations. 15798. https://lib.dr.iastate.edu/ etd/15798.

57. Roper, C. G., Rumble, J. N., Ma, Y., \& Irani, T. A. (2015). Talking local: Florida consumer definitions of local food. Gainesville: University of Florida Institute of Food and Agricultural Sciences. Retrieved from http://edis.ifas.ufl.edu/DLN

58. Schnell, S. M. (2013). Deliberate identities: Becoming local in America in a global age. Journal of Cultural Geography, 30(1), 56-89.

59. Schwartz, J. D. (2009, June 11). Buying Local: How It Boosts the Economy. Retrieved December 4, 2019, from http://content.time.com/time/ business/article/0,8599,1903 $632,00 . \mathrm{html}$.

60. Seyfang, G. (2006). Ecological citizenship and sustainable consumption: Examining local organic food networks. Journal of Rural Studies, 22, 383-395.

61. Shin, Y. H., Hancer, M., \& Song, J. H. (2016). Self-Congruity and the Theory of Planned Behavior in the Prediction of Local Food Purchase. Journal of International Food \& Agribusiness Marketing, 28(4), 330-345.

62. Sumarwan, U., \& Palupi, E. (2017). Preferensi Konsumen terhadap Buah-buahan Lokal dan Organik serta implikasinya terhadap Pendidikan Konsumen Cinta Produk Nasional, Jurnal Ilmu Keluarga dan Konseling, 10(2), 157-168.

63. Sumawidari, IAK., Darmawan, D. P., \& Astiti N. W. S. (2013). Faktor-Faktor yang Menentukan Permintaan Buah Lokal pada Hotel Berbintang di Kota Denpasar dan Kabupaten Badung. Jurnal Manajemen Agrbisnis, 1(1)

64. Trivette, S. A. (2015). How local is local? Determining the boundaries of local food in practice. Agriculture and Human Values, 32(3), 475-490.

65. United Nations. (n.d.). Sustainable consumption and production. Retrieved December 4, 2019, from https://www.un.org/sustainabledevelopment/ sustainable-consumptionproduction/.

66. Vecchio, R. (2010). Local food at Italian farmers' markets: Three case studies. International Journal of Sociology of Agriculture and Food, 17, 122-139.

67. Vermeir, I., \& Verbeke, W. (2008). Sustainable food consumption among young adults in Belgium: Theory of planned behaviour and the role of confidence and values. Ecological Economics, 64(3), 542-553.

68. Vickitra A., Ekowati, T., \& Prastiwi, W. D. (2017). Kesediaan Membayar Produk Sayuran Organik di Pasar Modern Jakarta Selatan. AGRARIS: Journal of Agribusiness and Rural Development Research 3(2), 67-75.

69. Wahyudi, A., Kuwornu, J. K. M., Gunawan, E., Datta, A., \& Nguyen, L. T. (2019). Factors Influencing the Frequency of Consumers' Purchases of Locally-Produced Rice in Indonesia: A Poisson Regression Analysis. Agriculture, 9(6), 117.

70. Waltz, C. L. (2010). Local Food Systems: Background and Issues. New York: Nova Science Publishers, Inc. 
71. Weatherell, C., Tregear, A., \& Allinson, J. (2003), In search of the concerned consumer: UK public perception of food, farming and buying local. Journal of Rural Studies, 19(2), 233-233.

72. Wilkins, J.L., Bowdish, E. and Sobal, J. (2002), Consumer perceptions of seasonal and local foods: a study in a US community. Ecology of Food and Nutrition, 41(5), 415-439.

73. Wiraraja, I., Windia, I., \& Sudarta, I. (2016). Dampak Alih Fungsi Lahan Sawah Petani Pemilik terhadap Kehidupan Rumah Tangganya (Studi Kasus di Subak Lange, di Kawasan Desa Pemecutan Kelod, Kecamatan Denpasar Barat). Jurnal Agribisnis Dan Agrowisata.

74. Wirawan, I G. P., Julyasih, K. S. M., Adiartayasa, W., Wijaya I N. \& Anom, I P. (2014). Increasing Local Fruits Competitiveness in Entering the Tourism Market in Bali. International Journal of Biosciences and Biotechnology. II(1), 20-25.

75. Zepeda, L. \& Leviten-Reid, C. (2004), Consumers' views on local food. Journal of Food Distribution, 35(3), 1-6.

76. Zepeda, L. \& Jinghan, L. (2006), Who Buys Local Food? Journal of Food Distribution Research, 37(3): 1-11. 